Revista de Ciencias Sociales - Número 64 (2014) - Páginas 125-168

Valoración de la declaración del imputado a la luz de la presunción...

\title{
VALORACIÓN DE LA DECLARACIÓN DEL IMPUTADO A LA LUZ DE LA PRESUNCIÓN DE INOCENCIA
}

\author{
CONSIDERING THE ACCUSED'S STATEMENT \\ IN LIGHT OF THE PRESUMPTION OF INNOCENCE
}

\author{
SOLEDAD PIÑEIRO* \\ Universidad Austral de Chile \\ mpineirof@gmail.com
}

\section{Resumen}

El paso de un sistema inquisitivo a uno acusatorio impuso varios desafíos a los operadores del sistema procesal penal. En ese contexto la presunción de inocencia se eleva como un pilar fundamental que ilumina todo su desarrollo. En esta oportunidad abordaré su relevancia en conexión a la declaración del acusado, medio de defensa, que impone el respeto de una serie de garantías procesales, para poder efectuar su valoración en juicio, considerada en sí misma, para luego ser ponderada en relación a otros medios de prueba, tanto de cargo como de descargo. Esta situación, que parece ser evidente y básica, no resulta ser tan clara al momento de resolver un caso concreto en juicio.

\section{Palabras claves}

Presunción de inocencia, valoración de la prueba penal, declaración del acusado.

\footnotetext{
* Abogada. Jueza titular del Tribunal Oral en lo Penal de Valdivia. Artículo recibido el 27 de marzo de 2014 y aceptado el 28 de mayo de 2014.

Revista de Ciencias Sociales - Número 64 (2014) - Universidad de Valparaíso - ISSN 0716-7725-Valparaíso, Chile
} 


\begin{abstract}
The switch from an inquisitorial to adversarial imposed several challenges to operators of criminal procedure. In this context, the presumption of innocence stands as a cornerstone that illuminates all their development. This time will address its relevance in connection with the statement of the accused, a defense, which imposes the respect of a number of procedural safeguards, to allow for proper valuation trial, considered in itself, only to be weighted in relation to other evidence, both charge and discharge. This situation, which seems to be obvious and basic, not be so clear when solving a particular case on trial.
\end{abstract}

\title{
Keywords
}

Presumption of innocence, evaluating evidence, criminal-defendant's statement.

\section{BREVE ANÁLISIS HISTÓRICO}

Para la mayoría de los autores el reconocimiento normativo de la presunción de inocencia tiene su origen histórico en la Declaración de los Derechos del Hombre y el Ciudadano de 1789 en cuyo artículo $9^{\circ}$ establece "Puesto que todo hombre se presume inocente mientras no sea declarado culpable, si se juzga indispensable detenerlo, todo rigor que no sea necesario para apoderarse de su persona debe ser severamente reprimido por la ley"1.

No parece discutirse la relevancia que en la elaboración de esta garantía le cupo al Marqués de Beccaria, don Cesare Bonesana, quien en su obra "Dei delitti y delle pene", publicada por primera vez en 1764, expuso ideas fundamentales para el desarrollo del proceso penal, entre las que se comprende la presunción de inocencia, refiriéndose a ella al tratar la tortura: "Un hombre no puede ser llamado culpable antes de la

1. En contra GALLAHER, Alexander: La presunción de inocencia y la presunción de voluntariedad, Editorial Jurídica Conosur, Santiago de Chile, 1996 pág. 20, quien estima que el primer texto legal que contempló la presunción de inocencia fue el Art. 28, V, de la ordenanza Criminal francesa de 1670 o Código Criminal de Luis XIV al prescribir "todos se presumen buenos mientras no se pruebe que son malos".

Facultad de Derecho y Ciencias Sociales - Universidad de Valparaíso - Chile 
sentencia de juez, ni la sociedad puede quitarle la protección pública sino cuando se haya decidido que violó los pactos con los que aquella protección le fue acordada. ¿Cuál es, pues, el derecho, sino el de la fuerza, que concede poder a un juez para aplicar una pena a un ciudadano mientras se duda si es culpable o inocente? No es nuevo este dilema: o el delito es cierto o incierto; si es cierto, no le corresponde otra pena que la establecida por las leyes, y los tormentos son inútiles en tal caso, como inútil es la confesión del reo; si es incierto, no se debe atormentar a un inocente, porque tal es según las leyes un hombre cuyos delitos no están probados"2. Aquí el autor recoge la idea esencial de esta presunción, al señalar que se es inocente mientras no medie una sentencia condenatoria. Resulta relevante atender su reflexión sobre la relación del tormento y la declaración del acusado, sea que la existencia del delito sea cierta o incierta, pues en ambos casos lo estima innecesario. Más aún, considerando que el delito es cierto, estima incluso innecesaria la confesión del perseguido.

Esas ideas formaron parte de la reforma ilustrada del siglo XVIII, que luchaba contra el despotismo, y en materia penal, desde una perspectiva más humanista, contra la arbitrariedad de las decisiones judiciales y la dureza del sistema persecutor penal, cuya máxima expresión se encuentra en la tortura como mecanismo de obtención de prueba inculpatoria, esencialmente la confesión.

A pesar que aquel principio encontró eco en textos legales, especialmente desde que fue recogida en la Declaración de los Derechos del Hombre y el Ciudadano, determinar su sentido y la forma u oportunidad de aplicación ha dado pie para objeciones y oposiciones, las que en alguna medida se mantienen hasta nuestros días, dificultando la precisión del contenido de esta garantía y más aún su aplicación y control judicial.

Es así como la denominada Escuela Clásica, recogió estas ideas e impulsó su aplicación. Uno de sus principales exponentes, Francesco Carrara, consideró que la presunción de inocencia es un presupuesto de la ciencia penal, la que unida a otras garantías como la existencia de un juez natural, la imparcialidad del juzgador, el derecho a defensa y

2. BECARIA, Cesare: De los Delitos y de las Penas, Ediciones Libertador, Buenos Aires, 2005, (notas y traducción Francisco Tomás y Valiente) pág. 42.

Revista de Ciencias Sociales - Número 64 (2014) - Universidad de Valparáíso - ISSN 0716-7725-Valparaíso, Chile 
aún la proporcionalidad en la prisión preventiva, conforman un tipo de proceso penal ${ }^{3}$. Esta Escuela postuló que el proceso tenía dos fines básicos: castigar al que comete un delito, pero también evitar la sanción a un inocente, esto último como la protección necesaria del ciudadano común frente a la actividad punitiva del Estado, de tal modo que convierte esta presunción en un eje de desarrollo del proceso penal ${ }^{4}$.

3. POZO, Nelson "Presunción de inocencia o estado de inocencia en el nuevo proceso penal”. En: Gaceta Jurídica año 2006, n³13, Julio, pág. 19.

4. Por otra ruta, quienes postularon ideas vinculadas a estudios de las ciencias biológicas y sociales, no dieron el mismo valor a la presunción de inocencia. De este modo para Enrico Ferri, (FERRI, ENRICO Sociología Criminal, Editorial Valletta Ediciones, Buenos Aires, 2005, pág. 447 — primera edición 1884-), perteneciente a la Escuela Positiva, la presunción de inocencia es ilógica si se la entiende en términos absolutos, pues precisamente el proceso se inicia por considerar que determinada persona está involucrada en ciertos hechos considerados delitos porque precisamente existen sospechas de su participación. De allí que estima no puede ser utilizada en casos de delincuentes habituales o en formas de criminalidad atávica. Expone que la presunción de inocencia debe ser un elemento que favorezca al ciudadano común, aludiendo claramente a una conducta pretérita intachable, al menos desde el punto de vista penal, pero no puede favorecer al delincuente habitual, ideas que concuerdan con el desarrollo de teorías relativas al comportamiento humano relacionadas con las características antropomorfas del sujeto. Este autor considera que se trata de un "aforismo jurídico", por lo que, una vez que su consideración es eliminada durante el curso del procedimiento, consecuencialmente suprime cualquier fundamento útil para sustentar disposiciones procesales "que en ella se inspiran y que son verdaderamente contrarias a las razones más claras de justicia y utilidad social", afirmación en clara sintonía con la idea que, en determinados casos, la presunción de inocencia no puede ser invocada como fundamento para mantener en libertad a delincuentes habituales, por ejemplo, durante el desarrollo del proceso. En ese sentido estima que es necesario poner un mayor énfasis en el resguardo del interés social, y en consecuencia se justifica aplicar medidas como la prisión preventiva, en contra de ese tipo de sujetos, respecto de quienes ese "aforismo jurídico" tiene un menor peso o validez.

Otro grupo de críticos más radicales, entre ellos Manzini, estiman que el proceso penal tiene por una parte la función de sancionar el delito en pos de proteger un interés social como es el reprimir la delincuencia, estrategia que debe primar por sobre la otra función del proceso cual es la de tutelar un interés individual de libertad. Los exponentes de esta corriente consideran que más que una presunción de inocencia lo que existe es una presunción de culpabilidad, lo que en definitiva justificaría la imposición de medidas cautelares. Para una más completa visión histórica ver VEGAS, Jaime: Presunción de Inocencia y Prueba en el Proceso Penal, Editorial La Ley, Madrid, 1993, págs. 25 y sig.

Facultad de Derecho y Ciencias Sociales - Universidad de Valparaíso - Chile 
A partir de la Declaración de los Derechos del Hombre y del Ciudadano, han sido varios los textos de carácter internacional que han recogido este principio. Es así como en 1948 la Asamblea General de la ONU, emitió la Declaración Universal de Derechos Humanos, cuyo artículo 11 expresa "1.- Toda persona acusada de delito tiene derecho a que se presuma su inocencia mientras no se pruebe su culpabilidad, conforme a la ley y en juicio público en el que se le hayan asegurado todas las garantías necesarias para su defensa" ". Luego en el año 1966 la Asamblea General adoptó el Pacto Internacional de Derechos Civiles y Políticos, que en su artículo 14.2 recoge el mismo principio "Toda persona acusada de un delito tiene derecho a que se presuma su inocencia mientras no se pruebe su culpabilidad conforme a la ley"6. Por último en 1969, se acordó la Convención Americana sobre Derechos Humanos, conocida también como Pacto de San José de Costa Rica, oportunidad en que se recogió este principio en términos similares a los ya referidos, especificando garantías mínimas que deben respetarse en el proceso penal, para asegurar el respeto y aplicación de aquella presunción ${ }^{7}$. De igual modo,

5. Publicada en "Tratados Internacionales vigentes en Chile en Materia de Derechos Humanos”, publicación especial del Diario Oficial de la República de Chile, marzo 1999, tomo I, pág. 182.

6. Tratado que entró en vigencia internacional para Chile el 10 de mayo de 1972, fue promulgado el 30 de noviembre de 1976 y publicado el 20 de abril de 1989. En "Tratados Internacionales vigentes en Chile en Materia de Derechos Humanos”, publicación especial del Diario Oficial de la República de Chile, marzo 1999, tomo I, págs. 90 y sig.

7. Artículo 8. Garantías Judiciales 2.- Toda persona inculpada de delito tiene derecho a que se presuma su inocencia mientras no se establezca legalmente su culpabilidad. Durante el proceso, toda persona tiene derecho, en plena igualdad, a las siguientes garantías mínimas:

a) Derecho del inculpado a ser asistido gratuitamente por el traductor o intérprete, si no comprende o habla el idioma del juzgado o Tribunal;

b) Comunicación previa y detallada al inculpado de la acusación formulada;

c) Concesión al inculpado del tiempo y de los medios adecuados para la preparación de su defensa;

d) Derecho del inculpado de defenderse personalmente o de ser asistido por un defensor de su elección y de comunicarse libre y privadamente con su defensor;

Revista de Ciencias Sociales - Número 64 (2014) - Universidad de Valparáíso - ISSN 0716-7725-Valparaíso, Chile 
la presunción de inocencia, poco a poco, ha sido recogida en muchos ordenamientos internos en forma expresa ${ }^{8}$.

En nuestro país esta garantía no fue recogida expresamente en la Constitución, aunque para algunos se puede desprender de lo dispuesto en el artículo $19 \mathrm{n}^{\circ} 3$ inciso 6. Sin perjuicio de aquella alternativa interpretativa, conforme lo dispuesto en el artículo 5.2 de la Carta Fundamental, se ha entendido incorporada a través de los tratados internacionales ya referidos, pasando a formar parte de nuestro ordenamiento interno - más allá de la discusión sobre la jerarquía de dichos cuerpos legales-, de tal modo que los órganos del Estado deben respetarla y promoverla.

\section{LA PRESUNCIÓN DE INOCENCIA Y SUS DIVERSAS DIMENSIONES}

Si bien la comunidad política ha advertido la necesidad de incorporar la presunción de inocencia en Textos Fundamentales, y en algunos de rango simplemente legal, como en el caso chileno — artículo

e) Derecho irrenunciable de ser asistido por un defensor proporcionado por el Estado, remunerado o no según la legislación interna, si el inculpado no se defendiere por sí mismo ni nombrare a defensor dentro del plazo establecido por la ley;

f) Derecho de la defensa de interrogar a los testigos presentes en el Tribunal y de obtener la comparecencia, como testigos o peritos, de otras personas que puedan arrojar luz sobre los hechos;

g) Derecho a no ser obligado a declarar contra sí mismo ni a declararse culpable, y

h) Derecho de recurrir del fallo ante juez o Tribunal superior.

En vigor internacional para Chile el 21 de agosto de 1990, promulgado el 23 de agosto del mismo año y publicado el 5 de enero de 1991. En "Tratados Internacionales vigentes en Chile en Materia de Derechos Humanos”, publicación especial del Diario Oficial de la República de Chile, marzo 1999, tomo I, pp. 147 y sig.

8. Así, entre los países latinoamericanos está contemplado en las Constituciones de Perú, Colombia, Ecuador, caso en la que se encuentra contemplada dentro de las garantías de un debido proceso, y México, a propósito del proceso penal. Lo mismo sucede con el Texto Fundamental de España que en 1978 la incluyó y la Constitución italiana, que en su artículo 27.2 señala "El acusado no será considerado culpable hasta que recaiga sentencia condenatoria firme", texto, cuya interpretación ha dado pie a muchas discusiones, las que no abordaré en esta ocasión.

Facultad de Derecho y Ciencias Sociales - Universidad de Valparaíso - Chile 
4 del Código Procesal Penal-, la mayor de las veces su contenido no se encuentra expresado en la norma, reduciéndose a una mera enunciación. Así resulta necesario buscar, dentro del cuerpo normativo, elementos que permitan darle contorno y sentido. Por ahora, se puede decir que aquella se centra en el proceso penal, el que debe estar legalmente establecido, pues en ese contexto se podrá determinar - o no- la culpabilidad del sujeto, proceso que debe desarrollarse con respeto a un mínimo de garantías, cuyo establecimiento se efectúa en función directa de aquella presunción, todas encaminadas a que la declaración de culpabilidad no sea arbitraria.

La amplitud de áreas en las que puede encontrarse aplicación a la presunción de inocencia exige un análisis diferenciado, a fin de ir precisando su forma de manifestación. En la doctrina nacional no es fácil encontrar referencias directas, ni precisas sobre cada una de estas formas de manifestación de la presunción de inocencia. Por regla general su acercamiento es en términos globales, más bien ligados a un significado histórico, sin advertir su evolución, que la ha asumido como una herramienta esencial en la praxis jurídico-penal, al convertirla en una regla en materia probatoria y una regla de juicio o decisoria.

\subsection{Reflexión sobre su estatus normativo}

Establecer cuál es la naturaleza o categoría de la presunción de inocencia ha presentado algunas dificultades, pues no todos consideran que se trata de una verdadera presunción, básicamente porque, de ser así, el mecanismo para configurarla debiera contemplar la prueba de un hecho del cual se deriva o presume tal inocencia, lo que sin duda en este caso no funciona de ese modo, pues no se requiere probar algo para que esta presunción opere?

9. ROMERO, Esteban: La presunción de inocencia. Estudio de alguna de las consecuencias de la constitucionalización de este derecho fundamental, Editorial Aranzadi, Pamplona, 1985, pág. 41 quien precisa: "la presunción de inocencia no es una verdadera presunción pues a través de ella no se prueba nada, no es por tanto un medio de prueba, ni surge de un hecho reconocido como cierto pues al contrario surge y tiene valor mientras no se practicó la prueba, o bien, cuando una vez practicada la prueba, el resultado de la misma no convenza al Juzgador de la certeza de lo que se pretende imputar al sujeto pasivo del proceso". En igual sentido GALLAHER, Alexander, ob. cit. págs. 5 y sig.

Revista de Ciencias Sociales - Número 64 (2014) - Universidad de Valparáiso - ISSN 0716-7725-Valparáís, Chile 
Por otra parte, hay autores y alguna jurisprudencia ${ }^{10}$ que consideran que aquella se trata de un presunción iuris tantum, es decir establecida por la ley, pero que admite prueba en contrario, cuestión que resulta coherente con la idea de considerar al acusado inocente hasta que se rinda válidamente prueba que acredite su participación culpable. Sin embargo, ello no se ajusta a las otras dimensiones que resulta necesario considerar, como son la presunción de inocencia como regla de prueba y como regla de juicio. Esta formulación sólo dice relación con el concepto básico de presunción de inocencia.

Para otros, la presunción de inocencia es un principio que informa todo el proceso penal, aproximación que permite expandir la presunción de inocencia a diversas áreas vinculadas al proceso penal, como el trato que debe prestarse al imputado, durante la investigación dirigida en su contra. Sin embargo, tal apreciación presenta como principal dificultad la casi imposibilidad de ejercer un control jurídico, pues el respectivo recurso debería fundarse en que no se ha aplicado un principio — normalmente herramienta de interpretación—, por sobre normas positivas.

Pretendiendo superar esta última dificultad, y a fin de entregarle un alcance dogmático con resonancia en la práctica, se ha postulado que en realidad la presunción de inocencia es una garantía fundamental pues ella orienta todo el proceso penal, surgiendo como una necesidad de protección del perseguido frente al poder punitivo del Estado y de toda la estructura burocrática y represora con que éste cuenta para ejercer dicha función. De ese modo, no puede perderse de vista que desde una

10. Así lo ha declarado el Tribunal Constitucional español, en su precursora sentencia de 28 de julio de $1981, \mathrm{~N}^{\circ} 31 / 1981$, en fundamento jurídico $\mathrm{n}^{\circ} 2$ expone "Una vez consagrada constitucionalmente, la presunción de inocencia ha dejado de ser un principio general del derecho que ha de informar la actividad judicial (in dubio pro reo) para convertirse en un derecho fundamental que vincula a todos los poderes públicos y que es de aplicación inmediata, tal como ha precisado este Tribunal en reiteradas Sentencias. En este sentido la presunción de inocencia está explícitamente incluida en el ámbito del amparo y al Tribunal Constitucional corresponde estimar en caso de recurso si dicha presunción de carácter iuris tantum ha quedado desvirtuada". También es considerada presunción iuris tantum por JAEN, Manuel: "La Presunción de Inocencia”. En: Revista Procesal Penal, n² 28, 2004 Editorial Lexis Nexis, pág. 41.

Facultad de Derecho y Ciencias Sociales - Universidad de Valparaíso - Chile 
perspectiva política, la presunción de inocencia se vincula estrechamente a un Estado de Derecho, es decir, a uno en que se respetan las garantías fundamentales. Así las cosas, al otorgarle el rango de garantía, la presunción de inocencia adquiere máxima relevancia y su existencia no se hace ilusoria en el proceso penal, máxime cuando, acompañada de otras garantías procesales, como el derecho a defensa ${ }^{11}$, a no autoincriminarse o a recurrir ante un Tribunal superior ${ }^{12}$, le otorga un particular perfil al proceso penal, sosteniendo un equilibrio entre el acusado y la actuación del ente persecutor. Considerarla de este modo le otorga, como plus, el que su trasgresión sea tutelada jurídicamente, de tal modo que ya no es una "buena disposición" de los juzgadores frente al acusado, sino que un deber que ha de manifestarse en todas sus actuaciones. POBLETE se refiere a ella como "la garantía de la inocencia es una opción por la inmunidad de los inocentes, aún a riesgo de la impunidad de un culpable"13.

11. Considerando sus cuatro facetas, esto es, derecho a utilizar toda la prueba de que se dispone, derecho a practicar la prueba en el proceso, derecho a una valoración racional de cada prueba ofrecida, y derecho a que la decisión judicial sea motivada y justificada con la prueba rendida. FERRER, Jordi: "Derecho a la prueba y racionalidad de las decisiones judiciales”. En: Jueces para la Democracia ${ }^{\circ} 47$ julio de 2003, págs. 27 y sig.

12. Entre los autores nacionales NOGUEIRA, Humberto: El debido proceso en la Constitución y el sistema interamericano, Editorial Librotecnia, Santiago de Chile, enero 2007, págs. 80, 81 y 130, estima que la presunción de inocencia pasó de ser un principio general del derecho a un derecho fundamental desde la incorporación de la Convención Americana de Derechos Humanos al derecho interno. Sin perjuicio de referirse a ella también como una presunción iuris tantum o un estado jurídico de las personas. En el mismo sentido, agregando que también se trata de un límite para el legislador, MONTAÑEZ, Miguel: La presunción de Inocencia. Análisis doctrinal y Jurisprudencial, Aranzadi Editorial, 1999, pág. 38. FERNÁNDEZ, Mercedes: Prueba y presunción de inocencia, Editorial Iustel, Madrid, 2005, págs. 119 y sig. Aunque considerándolo nominalmente un principio lo trata como un derecho o garantía.

13. POBLETE, Orlando, "Presunción de Inocencia, Significado y Consecuencias" en Revista del Abogado n 14, 1998, pág. 28.

Revista de Ciencias Sociales - Número 64 (2014) - Universidad de Valparaíso - ISSN 0716-7725-Valparaíso, Chile 


\subsection{Como regla de trato del imputado}

Entendiendo la presunción de inocencia como una garantía que informa y sostiene todo el proceso penal, su íntima relación con otras garantías, deviene en que frente a la trasgresión de éstas se produce, generalmente, la infracción de aquellas. De este modo, se advierte que una de sus dimensiones es el derecho subjetivo a ser tratado, en todo momento, como inocente, lo que debe comprender tanto la etapa de investigación como el juicio mismo.

Sin perjuicio que esta dimensión de la presunción de inocencia se incardina directamente con la aplicación de medidas cautelares, las que para algunos resultan absolutamente improcedentes, por transgredir esta garantía, con especial referencia a la prisión preventiva ${ }^{14}$, en esta oportunidad me referiré especialmente a la declaración del imputado durante el período de investigación y a la forma en que ella debe ser obtenida para luego ser valorada, a la luz de esta garantía.

Asumiendo que en un sistema acusatorio la declaración del imputado ya no es el centro de la actividad probatoria y, por el contrario, es prescindible, cuando ella se incorpora debe cumplir con ciertos requisitos que aseguren la libertad con que ésta fue entregada, de ese modo debe atenderse al momento en que se entrega, la persona que la recibe - un funcionario policial o un tercero- y el contexto en que se desarrolla, sólo luego de analizar esas condiciones será posible revisar su contenido ${ }^{15}$.

$\mathrm{Al}$ respecto es indispensable considerar que la prisión preventiva ${ }^{16}$ puede ser un elemento que condicione o altere el contenido de la

14. FERRAJOLI, Luigi: Derecho y Razón, Editorial Trotta, 2006, págs. 551 y sig.

15. FERRAJOLI, Luigi: ob. cit., pág. 604 "Mientras el método inquisitivo expresa una confianza tendencialmente ilimitada en la bondad del poder y en su capacidad de alcanzar la verdad, el método acusatoria se caracteriza por una desconfianza igualmente ilimitada del poder como fuente autónoma de la verdad”.

16. Analizando sentencias del TC español, MONTANEZZ, Miguel: ob. cit., concluye que la prisión preventiva es procedente y compatible con la presunción de inocencia cuando aquella pretende evitar la fuga, lo que se relaciona con la gravedad del delito y de la pena, así como también a las circunstancias concretas

Facultad de Derecho y Ciencias Sociales - Universidad de Valparaíso - Chile 
declaración del imputado, prefiriendo autoincriminarse, ya sea buscando un beneficio posterior o una posibilidad de libertad inmediata, o simplemente terminar más rápido con el proceso, de ese modo esta medida cautelar puede convertirse una presión indebida y en consecuencia ser atentatoria contra esta garantía, en su dimensión de regla de prueba, al interferir en la libertad con que este medio probatorio es obtenido.

\subsection{Como regla de prueba y regla de juicio}

La presunción de inocencia no tiene sólo aplicación en el ámbito de tratamiento al imputado, sino que es indispensable considerarla dentro del proceso decisorio propiamente tal. Así, debe ser tenida en cuenta al momento de definir cuál será la declaración del imputado que será valorada —en principio, y por mandato del artículo 296 del Código Procesal Penal, ha de ser la prestada en juicio, pero veremos

del caso y a la persona del imputado, elementos que pueden cambiar durante el procedimiento, permitiendo, también, modificar las cautelares adoptadas contra el perseguido. De igual forma pueden establecerse para evitar la obstrucción a la investigación, como en el caso de temerse la desaparición de prueba. Este autor agrega que el TC español ha establecido tres requisitos que permitirían la procedencia de la prisión preventiva: a) indicios racionales de la comisión de un delito; b) que tenga un fin constitucionalmente legítimo, y que no sea retributiva, pues faltando la dictación de sentencia definitiva sobre el caso, aún no existe condena. Agrega que la alarma social no es un fin legítimamente constitucional que deba ser resguardado por esta vía, y c) se adopte o mantenga, considerando que se trata de una medida que ser adoptada en forma excepcional, subsidiaria, necesaria y proporcionalmente. Siguiendo a FERNÁNDEZ, Mercedes: ob. cit. págs. 40-41, puede decirse que, intentando mantener el equilibrio entre el respeto de la presunción de inocencia y la efectividad de la persecución penal, las medidas cautelares resultan procedentes sólo cuando se presenten los presupuestos legales y su finalidad sea únicamente cautelar, no represiva, preventiva, ni de impulso a la investigación. Es así como estima que su única finalidad es la de garantizar que el proceso se lleve a cabo, lo que significa que sólo se justifican si existe peligro de fuga o un riesgo concreto de ocultación o alteración de pruebas.

Revisando la normativa contemplada en nuestro proceso penal, parece posible concluir que estos mismos parámetros han sido considerados por nuestro legislador, al menos en el diseño original, de la normativa, la que sufrió algunas modificaciones que han alterado esos objetivos.

Revista de Ciencias Sociales - Número 64 (2014) - Universidad de Valparáíso - ISSN 0716-7725-Valparaíso, Chile 
que no es la única que puede ser ponderada-, o si es posible no considerar la prestada durante la investigación, atendiendo a la forma en que fue obtenida, por ejemplo. Luego será necesario ponderar una eventual contradicción entre lo afirmado durante la investigación y luego en el juicio. Sin perjuicio, de esa valoración individual, luego es preciso relacionarla con el resto de la prueba de cargo, debiendo exigir una mínima actividad probatoria por el ente acusador, para luego ponderar la sustancialidad de la misma.

Después de precisar cómo y cuándo debe ser obtenida, rendida y valorada la prueba, resulta indispensable procurar otro grupo de reglas que nos indiquen la mejor forma de tomar una decisión, considerando el resto de la prueba presentada y valorada - tanto de cargo como de descargo-, en cuyo contexto debe ser sopesada la declaración del imputado.

\section{SISTEMA PROCESAL CHILENO Y LA GARANTÍA DE PRESUNCIÓN DE INOCENCIA}

Habiendo analizado cuales son las áreas en que la presunción de inocencia ha de ser considerada, es necesario verificar la forma en que ella es recogida y tratada dentro de nuestro ordenamiento jurídico interno.

\subsection{Recepción en normas Constitucionales y Tratados Internacionales}

Como se dijo anteriormente, nuestra Carta Fundamental no ha recogido expresamente esta garantía. A pesar de la opinión de algunos autores, no parece posible desprenderla de lo previsto en el artículo 19 $\mathrm{n}^{\circ} 3$ inciso $6^{\circ}$, que señala "La ley no podrá presumir de derecho la responsabilidad penal”, pues, por de pronto, tal disposición no excluye las presunciones simplemente legales, normas de las que no está exento nuestro Código Penal, desnaturalizando la esencia de la presunción de inocencia, obligando al acusado a una prueba diabólica o imposible de ofrecer ${ }^{17}$.

17. A modo de ejemplo podemos citar el artículo 445 del Código Penal que dispone "El que fabricare, expendiere o tuviere en su poder llaves falsas, ganzúas u

Facultad de Derecho y Ciencias Sociales - Universidad de Valparaíso - Chile 
Sin embargo, luego de la modificación introducida por la Ley 18.825, en agosto de 1989, al artículo 5 de nuestra Carta Fundamental, esa falencia parece haber desaparecido. El segundo inciso incorporado a la norma señalada expresa: "El ejercicio de la soberanía reconoce como limitación el respeto a los derechos esenciales que emanan de la naturaleza humana. Es deber de los órganos del Estado respetar y promover tales derechos, garantizados por esta Constitución, así como por los tratados internacionales ratificados por Chile y que se encuentren vigentes", de este modo podemos entender plenamente incorporados a nuestra legislación interna la garantía de presunción de inocencia conforme lo dispuesto en el artículo 14.2 del Pacto de Derechos Políticos y Civiles y artículo 8.2 de la Convención Americana de Derechos Humanos ${ }^{18}$.

Surge, ahora, otro problema, determinar la jerarquía que tiene esa garantía al haber sido incorporada de la forma descrita, pues tal decisión incidirá en el mecanismo de limitación a la misma que resultará procedente, así como también el modo en que ha de resolverse un conflicto en que colisione la presunción de inocencia con otra norma, legal o constitucional. En definitiva, ello determinará su efectividad como garantía ${ }^{19}$.

Por de pronto, cabe considerar el pronunciamiento que realizó el Tribunal Constitucional en sentencia Rol n ${ }^{\circ} 346$ de 8 de abril de 2002 — en la que se declaró inconstitucional el Tratado que contiene el Estatuto De Roma de la Corte Penal Internacional ${ }^{20}$ — haciéndose cargo

otros instrumentos destinados conocidamente para efectuar el delito de robo y no diere descargos suficientes sobre su fabricación, expedición, adquisición o conservación, será castigado con presidio menor en su grado mínimo”, en igual sentido pueden observarse los artículo 444, 448 quater, y 454 del mismo texto legal. Todas normas que establecen presunciones de autoría, las que deben ser desvirtuadas por el imputado para evitar una sanción, alterando la carga probatoria.

18. En este sentido NOGUEIRA, Humberto: ob. cit. pág. 78.

19. Por ejemplo, de entenderse que tiene rango constitucional, puede también afirmarse, indiscutiblemente, que normas penales en que se presume la autoría, como las referidas, son inconstitucionales.

20. Aunque posteriormente, y reforma constitucional mediante, se dijo que sus normas orgánicas constitucionales no eran contrarias a la Constitución. Sentencia de 24 de junio de 2009 rit 1415-09.

Revista de Ciencias Sociales - Número 64 (2014) - Universidad de Valparáíso - ISSN 0716-7725-Valparáiso, Chile 
de este problema en los considerandos $59^{\circ}$ y siguientes, concluyendo que los tratados internacionales incorporados de acuerdo a lo previsto en el artículo 5.2 de la Constitución, no tienen jerarquía constitucional, sino una inferior, pues deben sujetarse a ella. Sin embargo, se desprende de la cita que hace a la opinión del profesor Alejandro Silva Bascuñán vertida en su obra "Tratado de Derecho Constitucional", que estima que son normas superiores a cualquier otra norma jurídica ${ }^{21}$.

En la misma línea se pronuncia el profesor BERTELSEN, cuya opinión es igualmente acogida por la sentencia ya referida, quien estima que el tratado internacional sobre derechos humanos tiene un rango supralegal, pero infraconstitucional, en base a que está sujeto a control constitucional, pues procede el recurso de inconstitucionalidad en su contra. Entrega, también, una razón histórica al referirse al texto original propuesto por las autoridades de gobierno al iniciar las negociaciones de reforma constitucional con los partidos de Concertación por la Democracia y Renovación Nacional. Al respecto señala que el texto propuesto era más amplio pues pretendía incorporar todas las "normas internacionales que comprometen a Chile", lo que implicada incluir, entre otras, las opiniones consultivas, las que claramente no pueden tener rango constitucional ${ }^{22}$. Igual posición adopta el profesor TAPIA con fundamento en que no puede entenderse que la reforma de esa norma ha dado lugar a una "reforma implícita" de la Constitución. Sin embargo, afirma que "nos parece evidente que el verdadero y legítimo propósito del nuevo inciso segundo del Art. $5^{\circ}$ consiste en la agregación automática al listado de libertades y derechos contenidos en el Art. 19 del $C P R$, de aquellos que contiene el tratado, y en la forma en que los

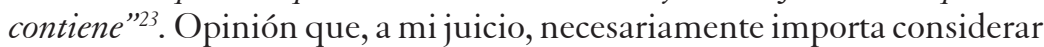

21. Para un análisis de la fundamentación que sobre esa materia contiene el fallo, ver DÍAZ, Luis: "La jerarquía constitucional de la presunción de inocencia en Chile". En: Revista de Derecho Universidad Católica de Temuco, n IV, octubre 2003.

22. BERTELSEN, Raúl: "Rango Jurídico de los Tratados Internacionales en el Derecho Chileno”. En: Revista Chilena de Derecho, Vol. 23 n 2 y 3, tomo I, año 1996, págs. 211 a 222.

23. TAPIA, Jorge: "Efectos de los Tratados sobre Derechos Humanos en la Jerarquía del Orden Jurídico y en la Distribución de Competencias: Alcances

Facultad de Derecho y Ciencias Sociales - Universidad de Valparaíso - Chile 
a la presunción de inocencia como una garantía más dentro de aquella norma constitucional, adquiriendo ese rango jurídico.

Otra ruta interpretativa han tomado algunos autores chilenos ${ }^{24}$, sosteniendo que los tratados internacionales sobre derechos fundamentales deben ser considerados con rango constitucional. Para ello han tenido en consideración que lo dispuesto por el inciso segundo al artículo $5^{\circ}$ de la Constitución, significa que la soberanía tiene como limitación los derechos esenciales que emanan de la naturaleza humana, ya sea que estén o no contemplados en la Constitución o en Tratados Internacionales, es decir, establece cómo se limita el ejercicio del poder. De este modo, la modificación sufrida por esa norma ha representado una ampliación del catálogo de derechos que constituyen esa limitación, pues lo ha extendido a las materias contempladas en esos Tratados Internacionales ${ }^{25}$, lo que significa la inclusión, como tal, de la presunción de inocencia. Sin embargo, agregan, ese catálogo no puede verse reducido a los derechos esenciales expresamente contemplados, lo único que ello realmente debe significar es la facilitación de su protección al no requerirse prueba de su existencia o condición, pues están expresamente reconocidos. De esta forma, en estricto derecho, no aparecía necesaria una reforma constitucional para darle jerarquía constitucional a los derechos humanos o esenciales a la naturaleza humana, pero con ella se avanzó en establecer una certeza jurídica al ampliar el listado de los mismos, además de reafirmar su jerarquía constitucional $^{26}$.

del nuevo inciso segundo del artículo $5^{\circ}$ de la CPR de 1980". Ius et Praxis. [online]. 2003, vol. 9, no.1 [citado 10 de octubre 2008], págs. 351-364. Disponible en la World Wide Web: <http://www.scielo.cl/scielo.php? script=sci_arttext\&pid=S0718$00122003000100017 \& \operatorname{lng}=\mathrm{es} \& \mathrm{nrm}=\mathrm{iso}>$. ISSN $0718-0012$.

24. Por todos MEDINA, Cecilia: "El Derecho Internacional de los Derechos Humanos”. En: Medina, Cecilia y Mera, Jorge: Sistema Jurídico y Derechos Humanos, Sociedad de Ediciones de la Universidad Diego Portales, 1996, pp. 27 a 84.

25. Sobre el punto es necesario considerar que existe discusión sobre qué debe entenderse por Tratados Internacionales que versen sobre derechos esenciales que emanan de la naturaleza humana, materia sobre la que no me extenderé en este trabajo.

26. En Opinión de MEDINA, Cecilia esta interpretación es aplicable no sólo a los tratados sobre de derechos humanos, sino también a cualquiera que contenga normas sobre aquellos. Ob. Cit. pág. 70.

Revista de Ciencias Sociales - Número 64 (2014) - Universidad de Valparáíso - ISSN 0716-7725-Valparaíso, Chile 
Finalmente, cabe mencionar que actualmente existe un proyecto de ley titulado "Reforma Constitucional que complementa el principio de presunción de inocencia penal" en primer trámite constitucional en el Congreso, esto es, ante la Comisión de Constitución, Legislación y Justicia de la Cámara de Diputados, desde el 2 de enero de 2007. En su parte considerativa se expone, entre otros, que la presunción de inocencia es un derecho fundamental, que debe vincular a todos los poderes públicos y personas, por ello estima necesario entregar una correcta interpretación del inciso $5^{\circ}$ del número 3 del artículo 19 de la Constitución, para garantizar un correcto ejercicio de este derecho humano fundamental, de tal modo que propone agregar la siguiente frase al final del inciso $6^{\circ}$ del número 3 del artículo referido: "Se vulnera este principio cuando una norma jurídica, autoridad, persona natural o jurídica impone sanciones o prohibiciones a alguien, basada en el mero hecho que sea judicialmente investigada" 27 . Por lo ya visto, claramente este proyecto de ley no incorpora expresamente en la Constitución la presunción de inocencia, aunque ofrece como aporte el considerar a la presunción de inocencia como un derecho fundamental, conforme se expone en la parte considerativa — no normativa- del proyecto.

De este modo, parece claro que no se ha recogido expresamente en nuestra Carta Fundamental esta garantía, sin perjuicio de no existir controversia sobre su incorporación a nuestro ordenamiento jurídico por intermedio de los tratados internacionales, de acuerdo a lo dispuesto en el artículo 5 inciso $2^{\circ}$ de la Constitución. Sin embargo, aún no es posible tener una opinión unánime en la doctrina sobre la jerarquía que ella ocupa internamente, aunque aparentemente no existe controversia sobre su rango supra legal.

\subsection{Tratamiento de la presunción de inocencia en normas legales}

El nuevo proceso penal, ha contemplado expresamente la presunción de inocencia como una garantía en el proceso penal. Es así como el artículo $4^{\circ}$ del Código Procesal Penal dice: "Presunción de

27. Boletín n 4767-07, moción del diputado Enrique Estay Peñaloza, sin urgencia y sin avances en su tramitación, a la fecha.

Facultad de Derecho y Ciencias Sociales - Universidad de Valparaíso - Chile 
inocencia del imputado. Ninguna persona será considerada culpable ni tratada como tal en tanto no fuere condenada por una sentencia firme". Claramente esta norma considera el concepto esencial de la presunción de inocencia, y por encontrarse bajo el Título I sobre Principios Básicos, sólo puede entenderse que su aplicación informa y sostiene todo el proceso penal. Sin embargo, no puede olvidarse que tal reconocimiento expreso sólo tiene rango de ley.

La norma citada, por de pronto, incorpora la presunción de inocencia como regla de trato, fase que se reafirma con lo dispuesto en el artículo 150 del mismo texto legal, que se refiere a la ejecución de la medida cautelar de prisión preventiva, señalando que "el imputado será tratado en todo momento como inocente", es decir, en el cumplimiento de la medida cautelar más grave, que supone la existencia presupuestos materiales serios en cuanto a la existencia del delito y la participación del imputado en él ${ }^{28}$, éste no puede dejar de ser tratado como inocente, pues aún no existe sentencia firme en su contra. Razonablemente, ese trato debe ser igualmente dispensado si el imputado se encuentra sometido a medidas cautelares menos gravosas, o a ninguna de ellas.

Otra alusión directa a esta garantía aparece en el artículo 44 del Código Procesal Penal, que faculta al Tribunal para restringir el acceso de terceros a los registros de la investigación, para evitar que se afecte el "principio de inocencia", en clara alusión a la aplicación de aquel como regla de trato, pues se pretende la protección del imputado, sustrayendo su situación procesal de la opinión pública. Además, el imputado no puede ser sometido a tortura ni a otros tratos crueles, inhumanos ni degradantes y su declaración no puede prolongarse excesivamente, prohibiéndose el interrogarlo bajo coacción, amenaza o promesa ${ }^{29}$.

28. Artículo 140 del CÓDIGO PROCESAL PENAL, sólo en cuanto a la exigencia de presupuestos materiales, dice "Requisitos para ordenar la prisión preventiva. Una vez formalizada la investigación, el Tribunal, a petición del Ministerio Público o del querellante, podrá decretar la prisión preventiva del imputado siempre que el solicitante acreditare que se cumplen los siguientes requisitos:

a) Que existen antecedentes que justificaren la existencia del delito que se investigare;

b) Que existen antecedentes que permitieren presumir fundadamente que el imputado ha tenido participación en el delito como autor, cómplice o encubridor, y

29. Artículos 93 letra h), 195 y 196 del Código Procesal Penal.

Revista de Ciencias Sociales - Número 64 (2014) - Universidad de Valparaíso - ISSN 0716-7725-Valparaíso, Chile 
Sobre la forma en que esta garantía es recogida como regla de prueba, aunque sin hacer alusión directa a ella, encontramos normas que le dan contenido ${ }^{30}$. Es así como al referirse al juicio oral el Código citado $^{31}$, en su artículo 295, contempla la libertad de prueba, lo que permite la rendición de cualquier medio probatorio, existiendo regulación sobre la oportunidad y forma de rendirla. En el mismo sentido el artículo 323 reafirma esta idea al establecer la posible incorporación de cualquier medio apto para producir fe — estimo debió decir convicción-, entregándole al juez la facultad para determinar la forma de incorporación.

Luego, en cuanto a la valoración de aquella, esto es, como regla de juicio, se entrega al juez libertad, pero éste en su decisión no puede infringir las reglas de la lógica, las máximas de la experiencia y los conocimientos científicamente afianzados ${ }^{32}$, es decir, el juez no puede decidir arbitrariamente, pues tiene límites que respetar dentro de su razonada resolución. A ello debe agregarse que la misma norma exige que el juez se haga cargo de cada una de las pruebas rendidas, ya sea para acogerlas o para desestimarla, expresando, también, con cuál de ellas ha tenido por acreditados cada uno de los hechos.

La valoración de los dichos del imputado se encuentra igualmente regulada en función de la presunción de inocencia. Por un lado el imputado o acusado es libre de declarar o no, pero si lo hace no es bajo juramento. Además su declaración debe ser considerada como un medio de defensa. Por último, no es suficiente prueba la declaración del acusado para ser condenado ${ }^{33}$.

De acuerdo a lo analizado en los acápites precedentes, es clara la deficiencia de nuestro ordenamiento jurídico interno en cuanto a contemplar expresamente la presunción de inocencia como una garantía

30. Sobre este tema se profundizará a continuación.

31. Normas que se aplican supletoriamente a todos los otros procedimientos establecidos en ese Código.

32. Art. 297 del Código Procesal Penal.

33. Arts. 297, 93 letra g), 98, 340 del Código Procesal Penal.

Facultad de Derecho y Ciencias Sociales - Universidad de Valparaíso - Chile 
o derecho fundamental, cuestión que se entiende subsanada por medio de la incorporación de los tratados internacionales a través de lo dispuesto en el artículo $5^{\circ}$ inciso $2^{\circ}$ de la Constitución, sin perjuicio de la discusión sobre su jerarquía dentro del sistema interno.

Por otro lado, nuestro proceso penal acoge aquella garantía en forma amplia, dando cuenta de su consideración en todas las dimensiones que la doctrina más moderna ha considerado que forman parte de ella. Es decir, como garantía que sostiene todo el proceso penal, como regla de trato, como regla de prueba y finalmente como regla de juicio. Sin embargo, y precisamente por su ubicación normativa, su aplicación se circunscribe exclusivamente al proceso penal y no a otros derechos sancionatorios como el administrativo, posibilidad se ha planteado doctrinariamente ${ }^{34}$.

\section{LA PRESUNCIÓN DE INOCENCIA COMO REGLA DE PRUEBA}

Esta regla está principalmente dirigida a los intervinientes y en especial al Ministerio Público, pues ella obliga a rendir prueba de cargo en el juicio oral y acreditar que fue obtenida en pleno respeto de las garantías procesales y derechos fundamentales. Por otro lado, a la defensa corresponderá efectuar el control horizontal, tanto de la forma y oportunidad en que la prueba es rendida, como de las circunstancias en que se obtuvo.

\subsection{Declaración del imputado como medio de defensa}

Teniendo ya un panorama general sobre cómo debiera operar la presunción de inocencia, como regla de prueba, nos encontramos con

34. En ese sentido DUCE, Mauricio: "Presunción de inocencia y estándar probatorio en sanciones administrativas: aclarando algunas cuestiones”. El Mercurio Legal, 11 de agosto de 2012, aunque reconoce que no es necesario exigir un mismo estándar probatorio que es establecido en el juicio penal. Por otra parte MONTAÑEZ, Miguel: ob.cit. págs. 58-65, hace un análisis en resoluciones de Tribunal Constitucional español, sobre su admisión en procesos de menores, civiles, laborales y contencioso administrativo.

Revista de Ciencias Sociales - Número 64 (2014) - Universidad de Valparaíso - ISSN 0716-7725-Valparaíso, Chile 
una primera situación que debemos analizar, el legislador nos indica que la declaración del imputado es un medio de defensa. Siguiendo a FERRAJOLI, esto significa que "tiene la única función de dar materialmente vida al juicio contradictorio y permitir al imputado refutar la acusación o aducir argumentos para justificarse" ${ }^{35}$, el autor señala que de allí se desprende el derecho a no declarar bajo juramento, a guardar silencio, a faltar a la verdad, a que su declaración no sea obtenida por medio de manipulaciones, como pueden ser las promesas de ciertos beneficios procesales o sancionatorios, o simplemente sometimiento a hipnosis o declaración bajo efectos de drogas ${ }^{36} \mathrm{y}$ a declarar en presencia de su defensor, como medio de control de abusos o violación de garantías procesales.

Nuestra legislación recoge no sólo la mención de la declaración del imputado como medio de defensa, sino varios de los elementos señalados y que le dan forma y sustento, como el derecho a guardar silencio, no declarar bajo juramento, lo que consecuencialmente acarrea la posibilidad de faltar a la verdad sin ser sancionado penalmente ${ }^{37}$.

El artículo 326 del Código Procesal Penal, señala las condiciones en que el acusado debe declarar, ello unido a la presencia esencial de su defensor y del fiscal, testimonio que presta ante los jueces, efectuándose una completa grabación del audio. De esa forma se protegen las garantías y derechos del acusado.

El artículo 296 del mismo texto legal señala que la prueba debe ser rendida y valorada en el juicio, de forma que debiera sólo el relato del acusado obtenido en esa oportunidad y de la forma legalmente prevista el que el tribunal debería ponderar. Sin embargo, por efecto del procedimiento contemplado en el artículo 332 del mismo Código, es posible conocer las actas en que se dejó constancias de sus dichos

\section{FERRAJOLI, Luigi: ob. cit. pág. 608.}

36. Sobre esta materia cabe considerar cómo se valora la declaración, espontánea o no, del acusado que estaba bajo la influencia del alcohol. Agregando que resulta necesario determinar a quién le corresponde probar el estado de temperancia del mismo.

37. Art. 93 letra g) del Código Procesal Penal.

Facultad de Derecho y Ciencias Sociales - Universidad de Valparaíso - Chile 
durante la investigación. Más aún, también es posible conocerla a través de los testigos de oídas.

En estas condiciones, resulta determinante verificar si esa declaración — no judicial — fue obtenida en respeto de garantías y derechos, como una primera cuestión a resolver, la que generalmente no ha podido ser sometida al control del Juez de Garantía, atendida la forma indirecta en que se presenta, ya que por impedirlo el artículo 334 del Código Procesal Penal, no es posible ofrecer dicha acta como medio de prueba para ser incorporada en el juicio. Más discutible resulta la existencia de ese control previo, cuando el testimonio es conocido por medio de testigos de oídas, caso en el que siempre quedará a salvo la posibilidad de su ponderación como medio de prueba no declarado nulo o ilícito.

En ese contexto, y como una primera aproximación debemos considerar si el hecho de poder aceptar responsabilidad penal para acceder a un procedimiento simplificado, o la aceptación de los hechos de la acusación y los antecedentes de la investigación, optando por un procedimiento abreviado ${ }^{38}$, decisiones que se pueden sustentar en un significativo cambio de la acusación y querella, de modo de adecuar esos requerimientos a las exigencias legales - lo que necesariamente importa una rebaja de pena- modificaciones que se consideraran no efectuadas — retomando la posibilidad de una sanción mayor- si el imputado no acepta responsabilidad o los hechos y antecedentes de la acusación, son situación que pudieran ser consideradas manipulaciones o presiones, que impidan un testimonio rodeado de las debidas garantías. A ello se agrega que en el juicio abreviado, por el solo hecho de esa aceptación, es posible reconocer al imputado una atenuante de responsabilidad penal, cual es la de colaboración sustancial al esclarecimiento de los hechos.

Es posible entender que ese riesgo ha sido asumido por el legislador - frente a la conveniencia de contar con fórmulas distintas al juicio oral para solucionar los conflictos penales - morigerando sus consecuencias, al ordenar al Juez de Garantía asegurarse que la

38. Arts. 388 y siguientes del Código Procesal Penal y arts. 406 y siguientes del mismo texto.

Revista de Ciencias Sociales - Número 64 (2014) - Universidad de Valparáíso - ISSN 0716-7725-Valparaíso, Chile 
declaración del acusado es efectuada en forma libre y voluntaria, al menos en el procedimiento abreviado ${ }^{39}$ y prohibiendo la aplicación de una sanción superior a la pedida por el persecutor penal, en el procedimiento simplificado, la que nunca puede superar el presidio menor en grado mínimo de modo que existe una alta probabilidad de que ella pueda ser cumplida en libertad. Sin embargo, ninguna de esas medidas asegura que la decisión ha sido tomada sin la presión psicológica a la que se enfrenta al imputado, al ofrecerle mejores condiciones, traducidas en penas menores. No puede dejar de tenerse en cuenta que normalmente a un sujeto no habituado al sistema, le resultará más complejo ponderar las ofertas, frente a la extendida creencia de un mal funcionamiento del sistema judicial.

Sobre este tipo de negociación procesal, FERRRAJOLI ha manifestado su férrea oposición, señalando "el resultado,... es, inevitablemente, la corrupción de la jurisdicción, la contaminación policial de los procedimientos y de los modos de investigación y de juicio y la consiguiente pérdida de la legitimación política o externa del poder judicial”40.

Luego, y volviendo ya a la declaración del acusado sobre los hechos imputados, es posible también observar que en los procedimientos policiales no se ha conocido una sistematización en orden a grabar por medio de video — o al menos sólo de sonido - las declaraciones de los imputados durante la investigación, de modo de poder establecer que ha dado real cumplimiento a prácticas prohibidas como los apremios, o los interrogatorios excesivamente prolongados o que provoquen agotamiento en el interrogado, amén de poderse constatar, sin lugar a dudas, la lectura o advertencia de sus derecho ${ }^{41}$. Tratándose de requisitos que forman parte de su declaración como medio de defensa, resulta necesario aportar los medios probatorios de establezcan el cumplimiento de estas exigencias, de lo contrario, y por

\footnotetext{
39. Art. 409 del Código Procesal Penal.

40. FERRAJOLI, Luigi: ob. cit. pág. 610.

41. Arts. 93 h), 195 y 196) del Código Procesal Penal.
}

Facultad de Derecho y Ciencias Sociales - Universidad de Valparaíso - Chile 
aplicación del la presunción de inocencia como garantía, debieran desecharse estas declaraciones, más aún cuando al prestarse en juicio, el acusado alega la trasgresión de esos derechos. En esta situación deberá preferirse la declaración prestada en juicio.

En ese sentido ha de considerarse lo resuelto por la Corte Suprema, en fallo sobre recurso de nulidad-Rol 4001-2010-, al acogerlo fundado en que la declaración tomada a un menor de edad durante la investigación no cumplió con los garantías generales de todo imputado, en este caso advertencia de poder guardar silencio, y las especiales de los menores, es decir, hacerlo en presencia de su defensor ${ }^{42} \mathrm{o}$ un adulto responsable. Lo que pudo establecerse por los dichos de algunos policías.

Estimo que no debiera ser exigible al imputado, prueba sobre esas falencias, sino que ha de ser el persecutor quien acredite el cumplimiento de exigencias legales, pues es él quien debe rendir una prueba lícita. Así lo afirma FERRAJOLI al señalar "En el modelo garantista se invierte la idea de que el fin de la verdad justifica cualquier medio, de modo que es únicamente la naturaleza del medio lo que garantiza la obtención del fin" ${ }^{\prime 3}$.

A propósito de la reciente modificación al artículo 102 del Código Procesal Penal, por la Ley 20.592, cabe preguntarse si la presencia del defensor es hoy una exigencia más rigurosa que en la antigua normativa. Pareciera que no, pues anteriormente la designación de defensor, desde la primera actuación del procedimiento, estaba a cargo del Ministerio Público o del Juez, hoy se eliminó esa responsabilidad al primero, de modo que si se trata de una detención de menos de 12 horas — plazo dentro del cual el Fiscal puede ordenar su libertad sin control judicialel imputado puede no contar con un defensor, pues los mecanismos legales han liberado al persecutor de la responsabilidad de esa presencia $^{44}$, dejando al perseguido en un situación anómala.

42. Art. 31 de la Ley 20.084.

43. FERRAJOLI, Luigi ob. cit., pág 608.

44. Ello, sin perjuicio que la anterior normativa también presentaba dificultades prácticas, en cuanto a la forma y oportunidad en que el persecutor cumplía esa carga.

Revista de Ciencias Sociales - Número 64 (2014) - Universidad de Valparáíso - ISSN 0716-7725-Valparaíso, Chile 
Otra situación que debe considerarse para valorar las condiciones en que la declaración no judicial se prestó es la ausencia de norma que imponga la obligación a las policías de someter a los imputados a examen médico para determinar su estado de temperancia alcohólica o la eventualidad de estar bajo efectos de algún otro tipo de drogas. Normalmente los imputados son llevados a constatar lesiones, precisamente como un resguardo a la debida actuación policial exenta de apremios ilegítimos, pero no contempla este tipo de examen clínico o químico, advirtiéndose en la práctica que muchas veces los facultativos no anotan si clínicamente han podido observar algún tipo de condición que revele ese estado. $\mathrm{Al}$ respecto, no puede olvidarse que someterse voluntariamente a algún tipo de drogas, si bien no importa una eximente de responsabilidad penal, objetivamente significa una distorsión de la percepción de la realidad, que debe tenerse en cuenta al momento de valorar los testimonios.

En este sentido la reforma planteada recientemente al proceso penal por el gobierno ${ }^{45}$, no contempla esta situación, lo que se echa de menos en torno a establecer condiciones óptimas para valorar la versión del imputado, respetando la presunción de inocencia.

Otro punto relevante, es atender a la calidad en que el imputado prestó su primera declaración, es decir, si lo fue en esa condición o como testigo, cuando aún la investigación no se dirigía en su contra. Más allá de la necesidad de establecer, de igual forma, que le fueron advertidos sus derechos como no declarar contra ciertos parientes o contra sí mismo, o en el caso de ser un menor de edad, hacerlo junto a un adulto responsable, aparece del todo necesario establecer que efectivamente hasta ese momento no se contaba con antecedentes policiales que pudieran incriminarlo, carga probatoria que debe soportar el Ministerio Público, aunque en un primer momento pareciera exigírsele la prueba de un hecho negativo, no es así, pues bastará con determinar cuándo se tomó conocimiento de los medios de prueba incriminatorios, en su contra. Incluso, parece razonable, considerar que en caso de duda, los policías opten por considerarlo imputado, advirtiéndole de ese modo

45. Boletín 8810-07 ingresado el 4 de marzo de 2013, con suma urgencia, actualmente en tramitación.

Facultad de Derecho y Ciencias Sociales - Universidad de Valparaíso - Chile 
sus derechos, entre ellos el de guardar silencio, o simplemente opten por no interrogarlo aún, hasta esclarecer su estatus procesal.

Se puede concluir que la declaración del imputado como medio de defensa, durante la etapa de investigación, ha de ser prestada en un contexto de pleno resguardo de sus derechos, de modo que ésta sea libre e informada de sus consecuencias ${ }^{46}$. En esta etapa cobra importancia la capacidad de las policías y del ente persecutor para establecer procedimientos de altos estándares de protección, de modo de evitar el cuestionamiento de un medio de prueba como este, pues debe tenerse en perspectiva que existe la posibilidad que el imputado decida no declarar en juicio o entregue una versión diferente, de forma que esa declaración cobrará una mayor importancia, pero sólo si ha sido obtenida con respeto - lo que deberá ser acreditado en juiciode todos su derechos y garantías.

\subsection{Sobre la oportunidad de la declaración durante el juicio oral}

Si bien en su momento hubo discusión sobre el momento en que el acusado podía prestar declaración en el juicio oral, a la luz de lo dispuesto en el artículo 326 del Código Procesal Penal, ya parece existir consenso en que puede concretarse en cualquier momento.

Así RIEGO, señala que el acusado puede declarar en cualquier momento del juicio, precisamente por tratarse de un medio de defensa, que supone la posibilidad de "responder, de hacerse cargo, de contradecir la prueba y los planteamientos de la parte acusadora", agrega que "Uno de los argumentos que se ha planteado a favor de la caducidad del derecho a declarar en el juicio, cuando éste no se ejerce en la etapa inicial, dice relación con el hecho de que la ley querría que el imputado declarara sin conocer en detalle la prueba de cargo. Esta circunstancia le impediría adaptar su declaración a lo que ha escuchado en el curso de juicio, lo que supuestamente le otorgaría a sus dichos un mayor valor informativo.

46. Así el artículo 93 letra g) del Código Procesal Penal en su actual redacción contempla la siguiente advertencia: "Tiene derecho a guardar silencio. El ejercicio de este derecho no le ocasionará ninguna consecuencia legal adversa; sin embargo, si renuncia a él, todo lo que manifieste podrá ser usado en su contra”.

Revista de Ciencias Sociales - Número 64 (2014) - Universidad de Valparáíso - ISSN 0716-7725-Valparaíso, Chile 
Incentivar al imputado a declarar al principio y plantear allí su versión, so pena de no poder hacerlo del todo, permitiría a los juzgadores valorar de mejor forma la credibilidad de la misma puesto que podrían luego confrontarla con el resto de las pruebas. Por el contrario, permitirle que declare después de la presentación de las pruebas hace perder esa posibilidad de confrontar la declaración con la prueba restante, porque le permite al acusado agregar a su declaración todos los elementos destinados a explicar, justificar o desmentir las afirmaciones de los demás testigos o demás medios de prueba, o evitar incluir en su declaración componentes que sean contradictorios con las declaraciones más creíbles" ${ }^{\prime 4}$.

En el mismo sentido se ha pronunciado nuestra Corte Suprema en causa Rol 7.351-2009 al señalar en su considerando duodécimo: "Que, si bien el artículo 326 del Código Procesal Penal, la ubica luego de los alegatos de apertura; $y$ más adelante, por su inciso final, permite que en cualquier estado del juicio pueda ser oído nuevamente pero para aclarar o complementar sus dichos; lo cierto es que conforme a lo afirmado en la parte final del motivo anterior, debe interpretarse integralmente como el derecho a defenderse en el momento que asi lo establezca el enjuiciado, incluso de acuerdo a consideraciones estratégicas. Sin embargo, no será neutra la consecuencia del momento que se elija para prestarla, pues si ello ocurre en etapas tardías del juicio, conlleva un eventual desgaste en la credibilidad de algunas de sus afirmaciones, pues se haría luego de haber escuchado todas las pruebas, a lo que cabe sumar que en todo caso, lo será con la limitante de que deberá soportar la carga de que sus dichos puedan ser utilizados como prueba en su contra y la obligación de someterse al contraexamen del o de los acusadores".

Me parece oportuno agregar que durante la investigación, salvo expresas excepciones legales, el imputado siempre tiene acceso a la prueba que recopila el Ministerio Público de modo que la ponderación de credibilidad del acusado no penderá de la oportunidad en que presté su testimonio, sino, como veremos más adelante, de su coherencia interna y externa.

47. RIEGO, Cristián: "La declaración del imputado en el juicio oral" págs. 8-9, http://enj.org/portal/biblioteca/penal/la_prueba_proceso_penal/19.pdf visitado el 6 de agosto de 2012.

Facultad de Derecho y Ciencias Sociales - Universidad de Valparaíso - Chile 


\subsection{La valoración de la declaración del imputado}

Siguiendo a NIEVA, resulta inevitable al momento de valorar un testimonio analizar la coherencia del relato, la contextualización del mismo, la existencia de corroboraciones periféricas por otros medios de prueba y la aparición de detalles oportunistas orientados a condicionar al oyente sobre la veracidad de su versión, sin que realmente añadan nada a aquella ${ }^{48}$.

Claramente la declaración del acusado prestada en juicio es la prueba que el Tribunal ha de valorar. Sobre el punto la ley establece un procedimiento respetuoso de sus derechos y garantías. Es así como, puede guardar silencio, en caso contrario, no declara bajo juramento, sólo es exhortado a decir verdad, de modo que sus eventuales faltas a ella no constituyen delito. Por otra parte, durante el desarrollo del juicio puede aclarar o completar su versión de los hechos, respetando su derecho a defensa. Finalmente existe obligación de grabar tanto su declaración como todo el juicio de forma que tal registro, puede ser objeto de control jurisdiccional. En ese contexto, la valoración formal de su versión en juicio no parece presentar dificultad, más aún cuando la entrega en presencia de su defensor y del fiscal del caso.

Ahora bien, esa versión, por mandato legal expreso ${ }^{49}$, no es suficiente para determinar responsabilidad penal, de modo que se hace necesario exigir al acusador una mínima actividad probatoria de cargo.

Como ya se explicó en el apartado anterior, nuestro sistema admite la posibilidad de conocer los dichos del acusado en la etapa de investigación, de forma que para valorar su versión ha de tener en cuenta tal situación. Es así como será necesario verificar si efectivamente el imputado declaró durante la investigación, luego controlar las condiciones en que se prestó, etapa en la que podría ser descartada como medio válido por no haberse acreditado el respeto de derechos y

48. NIEVA, Jordi "Inmediación y valoración de la prueba : El retorno de la irracionalidad”, pág. 8, visitado el 06/08/2012 en http://www.ichdp.cl/old/ inmediacion-y-valoracion-de-la-prueba-el-retorno-de-la-irracionalidad.pdf

49. Art. 340 inciso $3^{\circ}$ y 412 inciso $2^{\circ}$ del Código Procesal Penal.

Revista de Ciencias Sociales - Número 64 (2014) - Universidad de Valparáíso - ISSN 0716-7725-Valparáiso, Chile 
garantías. En este punto es donde la presunción de inocencia debe aplicarse para inclinar la balanza, pues, si corresponde al Ministerio Público rendir una prueba exenta de vicios, es decir, obtenida en cumplimiento con las garantías legales y constitucionales, la inexistencia de registros de resguardo, la deficiencia o imperfección de los mismos no puede sino obrar en su contra ${ }^{50}$, de forma que esa declaración del imputado no puede ser utilizada en juicio, o no debe operar en su contra.

Lo anterior desde un punto de vista formal y de algún modo más fácil de acreditar. Pero ahora surge otra dificultad, a la luz de los métodos y forma prohibida en los artículos 195 y 196 del Código Procesal Penal, ¿ puede entenderse que forma parte de esas fórmulas - todas tendientes a limitar la libertad de decisión del imputado- la oferta de beneficios - procesales o incluso penales - si declara? ${ }^{51}$ En concepto de FERRAJOLI, efectivamente son situaciones que alteran el estado de serenidad y autodefensa del imputado ${ }^{52}$. A ello se debe agregar que en este caso existe una dificultad probatoria cuya solución no debe pender del acusado. Así parece exigible que en los registros de la declaración se deje constancia de las explicaciones o advertencias efectuadas al deponente en ese orden. Pero, ¿̇cómo abordar la situación si, a pesar de las alegaciones del acusado, en ningún momento se efectuaron esas ofertas o si existen diferencias en cuanto a la forma y oportunidad en que se hicieron, conforme a sus dichos y los de los funcionarios que intervinieron en la diligencia? En estos casos aparece con claridad la necesidad que esos registros sean lo más fieles a la realidad y exento - $\mathrm{O}$ altamente improbables - de haber sido alterados, es decir, el deber de contar con registros de videos y audio, agregando elementos que permitan advertir — si la hay_ la existencia de alguna manipulación técnica, por ejemplo un reloj visible. Es decir, siempre es de cargo del ente persecutor presentar una prueba no objetable, respecto de las

50. Máxime cuando es una obligación llevarlos, conforme el artículo 97 del Código Procesal Penal.

51. Ya no en relación al tipo de procedimiento que eventualmente se aplicará, sino al hecho mismo de declarar sobre los hechos.

52. FERRAJOLI, Luigi: ob. cit., pág. 608.

Facultad de Derecho y Ciencias Sociales - Universidad de Valparaíso - Chile 
condiciones en que fue obtenida. En los casos en que este sistema no exista, se abrirá la posibilidad de plantear una duda que puede llegar a ser razonable o que simplemente permita desechar ese testimonio. Corresponderá al Tribunal, quien, atendiendo al resto de la prueba presentada, deberá ponderar el nivel de credibilidad que dará a los registros que le sean presentados. Parece razonable considerar que - en función de la presunción de inocencia, que impone la carga probatoria al persecutor- el Tribunal tenga en consideración cuántos y cuáles fueron los medios de resguardo de garantías que se concretaron en ese momento, pues en un contexto de escases de medios - al menos técnicos - ha de ponderar el respeto de esta garantía frente a otras con las que pudiera entrar en colisión.

Según MEDINA, en estos casos es necesario distinguir si se ha tratado de una promesa expresa, como una modificación de medida cautelar, o si se trata de conclusiones a las que arriba personalmente el imputado, última situación que no debiera considerarse como atentatoria contra su libertad de decisión ${ }^{53}$.

No podemos olvidar que el acusado también pudo haber declarado como testigo, circunstancia en la que será necesario revisar el cumplimiento de los estándares legales que en ese caso son exigibles, unidos a la acreditación de no haber existido antecedentes, en ese momento, que permitieran una persecución penal en su contra. También es posible que el imputado haya prestado declaración en forma espontánea, sin previa advertencia de sus derechos, caso en el cual, nuevamente será el persecutor quien debe acreditar la situación sorpresiva en que se conoció su relato.

Pues bien, si hecho ese análisis el Tribunal estima que la versión obtenida durante la investigación no ha cumplido los estándares legales, claramente ha de concluir que no se ha respetado la presunción de inocencia, debiendo valorar sólo la deposición conocida en juicio. No puede ser indiferente que la declaración del acusado haya sido obtenida con infracción de garantías, atendido el momento particular en que se

53. MEDINA, Gonzalo: "La primera declaración del imputado y el derecho a no declarar en perjuicio propio". En: Coloma, Rodrigo: La Prueba en el nuevo Proceso Penal Oral, Editorial Lexis Nexis, 2003, pág. 63.

Revista de Ciencias Sociales - Número 64 (2014) - Universidad de Valparáíso - ISSN 0716-7725-Valparáiso, Chile 
ha prestado, de modo que esa falta debe significar una desvaloración de aquella, siendo indispensable la fundamentación en la sentencia de esa decisión, pues esta será la única forma de verificar que ese relato ha sido realmente eliminado como fuente válida de información para formar convicción, especialmente de condena, oportunidad en que el o los jueces deberán explicar con claridad la prueba de cargo que los ha conducido a ella, prescindiendo absolutamente del relato del acusado, que han estimado alejado de la legalidad.

Otra situación que resulta necesario considerar, dice relación con declaraciones que haya prestado el acusado en contextos judiciales de otra índole, como en procesos civiles, de familia o administrativos. A primera vista, parece atendible exigir que esas declaraciones hayan sido prestadas en pleno conocimiento de sus derechos procesales penales, sin embargo, creo que, así como no resultan a priori despreciables las declaraciones espontáneas expresadas en el contexto de una investigación penal, debiendo ponderarse las circunstancias precisas en que se presta, es posible también ubicar a este tipo de declaraciones en ese nivel, es decir, no descartarlas a priori, recurriendo a estándares que -permitan considerar que ha existido una expresión libre de sucesos, con conocimiento de las consecuencias de sus asertos.

La mayor dificultad a la que se enfrentará el Tribunal, al momento de valorar los dichos del acusado, será cuando la o las versiones prestadas durante la investigación, por el acusado hayan cumplido todos los estándares legales, pero éstas sean contradictorias con la prestada en juicio.

Estimo que en esta situación —al igual que en el caso de no haber declarado el acusado en ningún momento, o de haberlo hecho sólo en el juicio- el Tribunal deberá atender básicamente a la prueba de cargo, como mínima actividad probatoria exigida por la ley, de forma de poder resolver cuál versión resulta más coherente con aquella —o ninguna- de modo que su deposición resulte complementaria o confirmatoria de aquella.

Aparecen dos situaciones más que atender, por una parte la mínima actividad probatoria que debe desplegar el Ministerio Público e, íntimamente relacionado a ello, determinar hasta qué punto la declaración del acusado ha de ser complementaria, es decir, que entregue

Facultad de Derecho y Ciencias Sociales - Universidad de Valparaíso - Chile 
información distinta, pero coherente y concordante con la de la prueba de cargo. Pero, a estas alturas, ya entramos en la presunción de inocencia como regla de juicio, por lo que retomaré el punto más adelante.

\subsection{Valoración de la declaración del imputado en relación a los coimputados y/o parientes}

Parece necesario definir si la presunción de inocencia obliga a elaborar un estándar distinto cuando estamos en presencia de una imputación efectuada por un coimputado o un pariente del acusado, de aquellos no obligados a declarar.

La valoración del relato del imputado finalmente siempre debe ser considerada en relación al resto de la prueba rendida, la que necesariamente debió ser previamente ponderada en forma individual de modo que pudo descartarse todo elemento que la vuelva poco creíble, imposible, impertinente o de algún otro modo desmerecer su valor de prueba. Sobre el punto, el legislador descartó la posibilidad de predeterminar la inhabilidad de testigos ${ }^{54}$, de modo que será el Tribunal el que, fundadamente y caso a caso, ha de analizar todo sesgo que impida la credibilidad del medio de prueba en particular, por lo que deberá considerar todas las particularidades del que individualmente valora, en la especie los dichos de un coimputado o de un pariente del acusado. Si bien es posible estimar que el primero pudiera intentar exculparse de responsabilidad penal imputando a su compañero de causa, también es posible elucubrar que se autoincriminará para relevarlo de responsabilidad, habiendo algún tipo de compensación desconocida de por medio. También puede imaginarse que el familiar del acusado - que a pesar de haberse eximido de declarar, lo hace-concurrió para apoyarlo en su particular teoría del caso. Pero, en la línea de las suposiciones, ese familiar también pudo asistir para inculparlo, como alguna forma de venganza, por alguna rencilla o conflicto no conocido. Siendo múltiples las posibilidades que subjetiva u objetivamente pudieran conducir a este tipo de testigos a faltar a la verdad, resulta indispensable que el Tribunal acuda a medios de prueba, que

54. Artículo 309 inciso primero del Código Procesal Penal.

Revista de Ciencias Sociales - Número 64 (2014) - Universidad de Valparáíso - ISSN 0716-7725-Valparaíso, Chile 
establezcan la existencia de una u otra circunstancias, de forma que en su ausencia habrá de considerar como válidos o plausibles sus testimonios, para luego valorarlos junto al del acusado.

Sin embargo, existe una necesaria consideración que ha de tener presente el Tribunal al valorar la declaración del coimputado, que éste no declara bajo juramento, como sí lo hace el pariente. Esta situación deberá ser pondera a la luz del resto de la prueba con la que se cuenta, pues sólo así se podrán resolver sobre su credibilidad. Dada esa condición resulta que pierde aptitud para que, por sí sola, sea suficiente como prueba de cargo, especialmente cuando es prestada en el mismo juicio. Surge la necesidad de dilucidar si la misma consideración ha de tenerse cuando, a pesar de ser enjuiciados por una mismo hecho, esto se hace en juicios distintos, y el coimputado, ya enjuiciado, declara, pues en esta ocasión desaparecen todas las motivaciones que pudieran torcer sus relato en orden a desvincularse, ya que su situación procesal está resuelta. De esa forma parece que en este caso su versión ha de ser considerada como la de otro testigo, sin las observaciones formuladas más arriba, salvo, claro está, que se pruebe alguna motivación espurea.

Así, en estos casos, el Tribunal deberá tener en cuenta, que la posible existencia de motivos que impulsen a ese tipo de testigos a faltar a la verdad sean, probabilísticamente, más altos que respecto de un testigo ajeno al acusado. Sin embargo, la necesidad de prueba será la misma.

\subsection{Acusado, muestras biológicas y reconocimientos}

Hasta ahora sólo he abordado la declaración del imputado. Sin embargo, aparece necesario considerar la posibilidad de obtener muestras biológicas desde el cuerpo del acusado, tal como lo contempla el artículo 197 del Código Procesal Penal. Dicha norma admite la posibilidad de obtener sangre u otras muestras biológicas de un imputado si este consintiere y de ello no se derivare un menoscabo para su salud o dignidad. Pero también permite que frente a una negativa, tal obtención se haga previa orden judicial, atendiendo a la misma limitación. Más allá del cuestionamiento que pudiera hacerse a la opción legislativa, desde el punto de vista de la presunción de inocencia como

Facultad de Derecho y Ciencias Sociales - Universidad de Valparaíso - Chile 
regla de prueba, cumplidos los requisitos y condiciones legales, esos medios de prueba han de ser valorados junto al resto de los elementos de convicción que se alleguen al juicio.

Distinta puede ser la situación cuando el imputado es sometido a una diligencia de reconocimiento. En efecto, en este caso la ley no regula un procedimiento estandarizado que garantice la objetividad de la diligencia y la protección del imputado. Sin embargo, frente a esa ausencia, y considerando el contenido de las garantías procesales, es perfectamente posible adoptar medidas que en la práctica se dirijan en ese sentido, agregando transparencia y credibilidad al proceso. Así las cosas corresponderá al juez evaluar las condiciones en que se ha practicado la diligencia, para luego concluir si ella es o no trasgresora de las garantías procesales, en términos muy similares a la propia declaración. No me parece despreciable considerar si el acusado consintió en ella, pues no existe impedimento, al menos legal, para ello. Además habrá de atenderse a la forma en que se ejecuta, si hay más personas presentes, las características físicas y de vestimentas de aquellos y su similitud con el imputado, las indicaciones entregadas previamente a la persona que hará el reconocimiento, las peticiones que se le hacen antes, durante y después de la diligencia, la forma en que ella se registra, etc. Así el juez determinará si no se ha trasgredido la presunción de inocencia, teniendo presente que ella comprende el derecho a guardar silencio, a no autoincriminarse y a la defensa, entre otros aspectos. Igual observación cabe efectuar cuando este reconocimiento es fotográfico. Sobre esta materia cabe tener presente que en la llamada "Reforma de la Reforma" en actual tramitación en el Congreso, se ha diseñado un sistema estandarizado para realizar este proceso, el que abarca algunos de los aspectos mencionados ${ }^{55}$.

\subsection{Valoración del silencio del acusado}

Teniendo presente que el imputado tiene derecho a guardar silencio, lo que se explica coherentemente con la exigencia normativa de ser el persecutor quien debe proporcionar la prueba de cargo, pues al perseguido lo ampara, precisamente, la garantía de la presunción de

55. Boletín 8810-07 de 4 de marzo de 2013, en el que se propone incorporar el artículo 196 bis, conteniendo una serie de reglas en este sentido.

Revista de Ciencias Sociales - Número 64 (2014) - Universidad de Valparáíso - ISSN 0716-7725-Valparaíso, Chile 
inocencia, cabe preguntarse si debe valorarse la actitud el imputado de ejercer ese derecho, es decir de no decir nada sobre la imputación, y en caso positivo cómo podría hacerse.

Como una primera aproximación podría decirse que es posible considerar dos extremos de ideas generales: si nada dijo nada hay que considerar y habrá que limitarse sólo al análisis de la prueba de cargo, o, frente a una acusación lo natural es que el imputado se defienda, si no lo hace es porque estima que la prueba en su contra es muy contundente. Veremos si alguna de ellas es aplicable o si es necesario acudir a una solución distinta.

Para abordar esta situación, resulta necesario hacer una distinción, que debería ofrecer soluciones diversas, considerando circunstancias distintas. Así, será diferente el caso en que el acusado ha guardado silencio total, es decir nunca ha dicho nada, ni durante la investigación ni en el juicio; de aquél en que el imputado entregó una declaración parcial, ya sea porque se ha referido sólo a algunos temas relativos a los hechos de la investigación, o porque no ha declarado en todas las etapas del procedimiento.

$\mathrm{Al}$ respecto RIEGO ha señalado: "Los jueces de cualquier juicio sabrán siempre que el acusado tuvo derecho a declarar y no lo hizo, y si es que del contexto de pruebas, ese hecho les permite hacer deducciones que fuercen la credibilidad acusatoria, entonces es perfectamente legítimo que lo hagan, dado que todo el juicio consiste en un conjunto de elementos de información que se produce de modo simultáneo e interactivo y es el conjunto de los mismos y de sus relaciones que los jueces utilicen este elemento de convicción en sus fallos, en realidad es obligatorio que lo hagan si es que le han dado valor, y también es perfectamente correcto que el o los acusadores de este elemento de análisis de la prueba". Más adelante agrega "El silencio del imputado, entonces, puede ser un elemento de reafirmación de la versión acusadora y, en el contexto de un caso sólido, puede ser un factor especialmente elocuente, pero su utilización no debe trasformarse en una especie de inversión de la carga de prueba por medio de la cual el caso del fiscal siempre aparezca validado por medio del silencio del imputado" ${ }^{156}$.

56. RIEGO, Cristián: La declaración del imputado en el juicio oral, pág. 21, visitado el 14 de julio de 2012 en http://enj.org/portal/biblioteca/penal/

Facultad de Derecho y Ciencias Sociales - Universidad de Valparaíso - Chile 
Considero que las explicaciones sobre por qué el acusado ha preferido guardar silencio - precisamente en el contexto de un juicio creado para su defensa- pueden ser varias e ir de un extremo a otro, es así como aquél puede estimar que no tiene explicación ante la contundencia de la prueba del acusador, o que — por el contrarioésta es tan débil que no necesita decir nada. Sin esa expresa explicación, y a la luz de la presunción de inocencia, el juez debe optar por la última alternativa y, en definitiva, avocarse a valorar la prueba que si le fue entregada en juicio. Ese silencio también puede responder a motivaciones estratégicas del proceso o muy ajenas a éste, como proteger a terceros involucrados, por ejemplo, si un sujeto es sorprendido con especies provenientes de un robo, su negativa a declarar puede ser estratégica, pues frente a la carencia de mejores pruebas, sólo podrá ser encausado como receptador, arriesgando una sanción considerablemente menor, y también esa negativa puede tener su justificación en evitar que su hijo — verdadero autor del ilícito- sea sancionado, pues hasta ese momento las pruebas sólo se dirigen en su contra. De allí que me parece muy relevante atender a la prueba de cargo y no a las posibles explicaciones que el silencio del acusado pueda tener, para luego darle algún valor, pues ello implica asumir un riesgo muy alto de condenar a un inocente. Es decir, el silencio es eso, silencio, nada posible de valorar.

Respecto de la afirmación de RIEGO en orden a que " $E n$ principio, la lógica indica que quien tiene una versión verdadera distinta a la inculpatoria debiera plantearla tempranamente con el fin de que ella sea incorporada en la investigación y validada por ésta"57, creo que sólo una vez analizada y valorada la prueba, y estimándola suficiente, teniendo por acreditados las proposiciones fácticas de la acusación, es posible considerar que el silencio del acusado refuerza ese proceso, pues no entregó una versión distinta que pudiera haberse considerado a la luz de la misma prueba rendida. Pero en ese caso, la valoración del

la_prueba_proceso_penal/19.pdf En el mismo sentido MONTAÑEZ, Miguel: ob. cit., págs. 137-138 al referirse a la doctrina del TS español, con base en sentencias de TEDH.

57. RIEGO, Cristián: ob. cit. pág. 21. 
silencio actúa, más bien, como una especie de chequeo de conformidad del proceso de valoración probatoria, pues no entregó elementos que la contradijeran, más no resulta ser complementaria ni confirmatoria, y por el contrario se cumple que el requisito de rendirse un mínimo de prueba de cargo válida y suficiente. En definitiva, pudo llegarse a esa solución sin atender a ese silencio.

No parece existir dificultad al valorar la declaración del acusado prestada en juicio, cuando no la haya rendido en la etapa de investigación, pues precisamente para esa etapa la ley reserva la rendición de la prueba, y en el caso de la declaración del acusado sus derechos se ven protegidos desde que está asesorado por su abogado defensor y le es advertido su posibilidad de guardar silencio, de modo que su declaración en juicio cumple todas las garantías procesales, pudiendo ser valorada íntegramente, sin importar la ausencia de relato anterior. Sin embargo, en este caso puede llegar a considerarse como elemento de falta de credibilidad el que no haya expuesto su teoría alternativa — como puede ser la de inocencia- desde un primer momento, instando por la realización de diligencias que permitieran establecer hechos que produzcan, a lo menos, una duda razonable sobre la existencia del hecho y/o de su participación. Enfrentados a esta situación nuevamente debemos considerar que los motivos - no revelados - que el imputado tuvo presente para sostener su silencio, pueden corresponder a muchas alternativas, no siempre relacionados con los hechos imputados ni con la prueba de cargo, de modo que la falta de conocimiento sobre esa eventual explicación, no puede operar en contra del acusado, de lo contrario estaríamos frente a una duda que operaría contra éste.

Siguiendo con el análisis de las situaciones que se pueden presentar, debemos considerar la posibilidad — no de poca ocurrenciaque el imputado que declaró durante la investigación, no lo haga en el juicio. En este caso su declaración será incorporada por medio de algunas de las formas establecidas en la ley, generalmente ocurre que es conocida a través de funcionarios policiales que la presenciaron, esto es, por medio de testigos de oídas, expresamente aceptados en nuestra legislación ${ }^{58}$. Pues bien, en este caso será necesario atender a las circunstancias en

58. Artículo 309 inciso final del Código Procesal Penal.

Facultad de Derecho y Ciencias Sociales - Universidad de Valparaíso - Chile 
que fue prestada. Acá, cobra relevancia la última modificación introducida al artículo 93 letra g) del Código Procesal Penal, al referir que la información de derechos al imputado debe contener la advertencia de que todo lo que declare podrá ser usado en su contra ${ }^{59}$, pues de esa manera es advertido que su declaración será considerada en juicio. Sin embargo, tal situación, no libera al ente persecutor de respetar - y acreditar - las garantías que rodearon esa diligencia. Además, claramente esa versión ha de ser valorada en conjunto con una mínima prueba de cargo.

Es contrario a la presunción de inocencia estimar que la ausencia de relato en el juicio tenga como significado el reconocimiento tácito de la imputación fiscal, pues el ente acusador no queda relevado de su obligación de acreditar los hechos y la participación, invocadas en su acusación. Siempre debe sostener sus afirmaciones fácticas con prueba suficiente.

Finalmente pareciera que una de las situaciones que presenta más dificultad es la valoración de un testimonio con silencios parciales, admitiendo que éste ha sido entregado en un contexto de pleno resguardo de garantías. Al valorar este relato no debe olvidarse que a la defensa le basta con introducir una duda razonable en la teoría del caso del persecutor, de modo que si esos silencios la construyen, entonces, la falta de explicación ha de ceder en favor del acusado. Por otra parte la incoherencia, externa o interna, de esa versión, precisamente por la omisión parcial de eventos, tendrá repercusión en la valoración que el tribunal efectúe de ella — en conjunto con el resto de la prueba-, sea para considerar que efectivamente ha podido introducir una duda razonable o para acreditar hechos distintos a los contemplados en la acusación y que sustentan su teoría alternativa.

\section{PRESUNCIÓN DE INOCENCIA COMO REGLA DE JUICIO}

Esta última forma de entender la presunción de inocencia, íntimamente ligada a la regla de prueba, está dirigida al juez, pues una

59. La Ley 20.592 agregó a esa norma que deber advertido al imputado textualmente que "Tiene derecho a guardar silencio. El ejercicio de este derecho no le ocasionará ninguna consecuencia legal adversa; sin embargo, si renuncia a él, todo lo que manifieste podrá ser usado en su contra”.

Revista de Ciencias Sociales - Número 64 (2014) - Universidad de Valparáíso - ISSN 0716-7725-Valparáiso, Chile 
vez efectuada la valoración de la prueba considerando su obtención con respeto de garantías y derechos, la oportunidad y forma de rendición, entre otros, ahora es necesario resolver si esa prueba resulta suficiente para acreditar los hechos de la acusación. Así lo indica FERNÁNDEZ ${ }^{60}$, "la función de regla de juicio asume un papel relevante en un momento posterior, concretamente cuando tras la valoración de la prueba practicada con todos las garantías (esto es, cuando ha sido superada la presunción de inocencia desde el punto de vista de su función como regla probatoria) el resultado que de ella se deriva no es concluyente y, por tanto, impide que el órgano judicial resuelva conforme a él. En estos casos la duda -como consecuencia de una prueba de cargo insuficiente - debe resolverse a favor del acusado por aplicación de la presunción de inocencia".

Entendida de esta forma, la presunción de inocencia como regla de juicio, nos lleva al estándar de la duda razonable ${ }^{61}$ — expresamente reconocido en nuestro sistema procesal penal en el artículo 340 del Código Procesal Penal- pues el juez ha de relacionar la prueba válidamente rendida, para determinar si con ella es posible acreditar, de la forma propuesta por el persecutor, los hechos imputados, o si por el contrario existen vacíos o contradicciones que impiden esa conclusión. En este punto la razonabilidad de la o las dudas planteadas por el juez, determinarán la decisión de absolución o condena. Íntimamente ligado a este estándar — cuya intrínseca dificultad práctica no abordaré en esta oportunidad - aparece la exigencia de una mínima actividad probatoria $^{62}$, es decir, la prueba de cargo que mínima y suficientemente acredite los hechos y la responsabilidad imputada, derrotando la presunción de inocencia.

Por de pronto esta regla impone considerar que la sola declaración del imputado no es suficiente para acreditar los hechos y su participación

60. FERNÁNDEZ, Mercedes: ob.cit., págs. 157-158.

61. Sobre su alcance y construcción, por todos ACCATINO, Daniela: Certezas, dudas y propuestas en torno al estándar de la prueba penal. En: Revista de Derecho de la Pontificia Universidad Católica de Valparaíso XXXVII, Valparaíso Chile $2^{\circ}$ semestre 2011, págs. 483-511.

62. Un extenso y acabado análisis en MIRANDA, Manuel: La mínima actividad probatoria en el proceso penal, José María Bosch Editor, Barcelona, 1997.

Facultad de Derecho y Ciencias Sociales - Universidad de Valparaíso - Chile 
en ellos, estándar que está recogido expresamente en nuestra legislación ${ }^{63}$. Ello tiene una doble justificación, por un lado se trata de otra medida de protección del perseguido, pues su versión puede obedecer a una gran variedad de medidas de presión y/o de protección a terceros, por otro, esta prohibición también importa una protección al sistema penal, disminuyendo considerablemente el margen de error, al minimizar el riesgo de condena de un inocente, exigiendo prueba distinta $-\mathrm{y}$ necesariamente desligada- del testimonio del acusado. $\mathrm{Al}$ respecto, no puede olvidarse que la condena a un inocente, siempre trae aparejada la falta de sanción al verdadero culpable, eliminándose, consecuencialmente, todos los efectos protectores de la persecución penal, como solución del conflicto social. En ese mismo sentido lo expresa FERRAJOLI, “...no puede tener ningún valor probatorio si no va acompañada de algún otro elemento de juicio, porque resulta inverosímil que, si es auténtica, el sedicente protagonista del delito no pueda aportar otras confirmaciones; y tendrá valor probatorio en la medida que vaya avalada por una pluralidad de datos y confirmaciones, según el principio de la fecundidad de las pruebas fiables..." ${ }^{64}$. De esa forma si el relato del acusado - aún cuando sea autoinculpatorio y especialmente cuando lo es- no tiene reflejo en prueba suficiente rendida por el persecutor, la presunción de inocencia, operando como regla de juicio, obliga al juez a declarar absolución. También lo afirma FERNÁNDEZ al señalar que "..es pacífica la idea de que la duda acerca de la existencia de los hechos constitutivos de la pretensión penal debe desembocar en la absolución del acusado, y ello con independencia de la actitud activa o pasiva por la que éste haya optado como estrategia defensiva"65.

Es decir, la condena debe fundarse en prueba válidamente emitida y lo suficientemente convincente para que no exista duda razonable tanto de la existencia del hecho ilícito como de la participación del acusado en ellos. Siguiendo DUCE y RIEGO ${ }^{66}$, la aparición de esa

63. Art. 340 inciso $3^{\circ}$ Código Procesal Penal "No se podrá condenar a una persona con el solo mérito de su propia declaración".

64. FERRAJOLI, Luigi: ob. cit., pág. 612.

65. FERNÁNDEZ, Mercedes: ob. cit., pág. 99.

66. DUCE, Mauricio y RIEGO, Cristián: Proceso Penal, Editorial Jurídica, 2007, págs. 497-502.

Revista de Ciencias Sociales - Número 64 (2014) - Universidad de Valparáíso - ISSN 0716-7725-Valparaíso, Chile 
duda surge cuando existe más de una hipótesis acreditable con los hechos probados, de forma que cada vez que el Ministerio Público cierre la posibilidad de acreditar una hipótesis distinta a la por él planteada, esa duda se irá disipando; por el contrario, cuando aquella hipótesis no arroje dudas sobre una lectura distinta de los hechos probados, o esté más lejos de aquella situación la duda dejará de ser razonable.

Por otra parte y partiendo de la base que el Tribunal ha determinado que la prueba de cargo rendida es suficiente para establecer los hechos y la responsabilidad penal, cabe considerar cómo se relaciona esa prueba con el testimonio del acusado. Así su versión puede ser confirmatoria de la tesis acusatoria, de forma que en este caso su valor será corroboración, no contradictoria. Otra situación a valorar, se presenta cuando el acusado entrega una versión cuyo contenido completa la prueba del acusador, es decir, entrega elementos que aquella prueba no aporta. En este caso es de alta prioridad tener presente el límite normativo de no poder condenar con la sola declaración del imputado, debiendo analizarse qué tipo de elementos son aquellos. Asî si resultan ser esenciales tanto para establecer la existencia del hecho como de la responsabilidad penal, no parece posible optar por una condena.

Ahora bien, otro problema a resolver se presentará cuando la versión del acusado resulta ser claramente contradictoria con la posible de ser construir con la prueba de cargo, esta será la ocasión en que la regla de juicio debe operar aplicándose el estándar de duda razonable, y en consecuencia resolviendo si aquella resulta suficiente para excluir otras versiones posibles, y además acreditar la propuesta por el persecutor. Pero además se puede presentar la situación en que además de la versión del acusado, éste haya rendido prueba conducente a corroborarla, en este caso la prueba puede situarse en tres estadios: a) que se acrediten los hechos en que se funda la versión exculpatoria del acusado, de forma que refute la prueba de cargo y en consecuencia será declarada la absolución; b) que, o no se rindió prueba o ésta ha sido insuficiente para apoyar esa versión, de modo que la prueba de cargo resulta suficiente para establecer la responsabilidad penal, y c) la prueba de la defensa es insuficiente para establecer su versión, ocasión que presenta la situación más compleja, y con una mayor discusión sobre cómo opera

Facultad de Derecho y Ciencias Sociales - Universidad de Valparaíso - Chile 
la presunción de inocencia. FERNÁNDEZ afirma "...la defensa tiene la carga de la prueba de los hechos impeditivos de la responsabilidad penal $y$, que, por el contrario, la duda acerca de alguno de ellos debe actuar en su beneficio: por su puesto en problema que se plantea en esta caso será el de determinar el quantum probatorio necesario para entender que el acusado ha cumplido con la carga de la prueba"67.

Sin lugar a dudas, en esta fase la fundamentación de la decisión judicial alcanza su mayor relevancia, tanto como comunicación a los intervinientes como por el más efectivo sistema de control judicial.

\section{CONCLUSIONES:}

1. La presunción de inocencia es una garantía procesal, no reconocida expresamente por nuestra Constitución, pero incorporada a través de los Tratados Internacionales de Derechos Humanos, de lo que se deriva la dificultad para determinar su jerarquía, sin perjuicio de ser indiscutible su superioridad sobre una ley. Además cuenta con expreso reconocimiento legal en materia procesal penal.

2. Esta garantía se expresa en diversas áreas, primero como sostenedora de todo el proceso penal, luego como regla de trato del imputado, pues a pesar de estar eventualmente sometido a medidas cautelares personales, su estatus de inocente se mantiene mientras no existe sentencia condenatoria en su contra.

3. Como regla de prueba, la presunción de inocencia está dirigida a los intervinientes, y especialmente al persecutor, pues, en su cumplimiento, debe obtener, y así acreditarlo, toda la prueba de cargo, respetando las garantías y derechos del imputado, incluida su propia declaración.

La trasgresión de ese mandato obliga a desechar esa prueba, de modo que si se trata de la declaración del acusado obtenida durante la investigación, y conocida en juicio conforme a los medios legalmente admitidos, deberá ser desechada y no valorada. Se debe recordar que por ser una admisión excepcional de esa medio de prueba, el control de legalidad no es efectuado por el Juez de Garantía.

67. FERNÁNDEZ, Mercedes: ob.cit., pág. 210.

Revista de Ciencias Sociales - Número 64 (2014) - Universidad de Valparáíso - ISSN 0716-7725-Valparaíso, Chile 
La falta de prueba sobre haber ajustado la conducta de los investigadores a esos parámetros, también orienta a la trasgresión de esta garantía, debiendo optarse por desechar ese medio probatorio. Sin perjuicio de la ponderación que deberá hacer el Tribunal sobre la trascendencia de aquella omisión.

4. Finalmente, aplicada como regla de juicio, es una exigencia dirigida al Tribunal, pues la prueba válidamente rendida, ahora deberá ser valorada para determinar si es suficiente para acreditar la hipótesis acusatoria. En esa dirección se deberá atender a la existencia, o no, de una duda razonable que impida esa convicción. En ese contexto, el Tribunal debe analizar la coherencia, completitud y discrepancia de la prueba, incluida la declaración del imputado. Ponderación cuyos parámetros o fórmulas decisorias, han de ser determinadas caso a caso, chequeando constante la validez de cada elemento probatorio, la obligación de rendir prueba de cargo por el persecutor y el relevo al acusado de presentar prueba exculpatoria. Esta última situación también obliga a ponderar de modo distinto la prueba presentada por el acusado, la que sólo cobrará real trascendencia cuando la de cargo sea suficiente.

\section{BIBLIOGRAFÍA}

ACCATINO, Daniela: Certezas, dudas y propuestas en torno al estándar de la prueba penal. En: Revista de Derecho de la

Pontificia Universidad Católica de Valparaíso XXXVII, Valparaíso Chile $2^{\circ}$ semestre 2011.

BERTELSEN, Raúl: "Rango Jurídico de los Tratados Internacionales en el Derecho Chileno". En: Revista Chilena de Derecho, Vol. 23 n $^{\circ} 2$ y 3, tomo I, año 1996.

DÍAZ, Luis: "La jerarquía constitucional de la presunción de inocencia en Chile". En: Revista de Derecho Universidad Católica de

Temuco, $\mathrm{n}^{\circ} \mathrm{IV}$, octubre 2003.

DUCE, Mauricio: "Presunción de inocencia y estándar probatorio en sanciones administrativas: aclarando algunas cuestiones". El

Mercurio Legal, 11 de agosto de 2012.

DUCE, Mauricio y RIEGO, Cristián: Proceso Penal, Editorial Jurídica, 2007.

FERRAJOLI, Luigi: Derecho y Razón, Editorial Trotta, 2006.

Facultad de Derecho y Ciencias Sociales - Universidad de Valparaíso - Chile 
FERNÁNDEZ, Mercedes: Prueba y presunción de inocencia, Editorial Iustel, Madrid, 2005.

FERRER, Jordi: Derecho a la prueba y racionalidad de las decisiones judiciales". En: Jueces para la Democracia n 47 julio de 2003.

FERRI, Enrico: Sociología Criminal, Editorial Valletta Ediciones, Buenos Aires, 2005.

GALLAHER, Alexander: La presunción de inocencia y la presunción de voluntariedad, Editorial Jurídica Conosur, Santiago de Chile, 1996.

JAEN, Manuel: "La Presunción de Inocencia". En: Revista Procesal Penal, $n^{\circ} 28,2004$ Editorial Lexis Nexis.

MEDINA, Cecilia: "El Derecho Internacional de los Derechos Humanos”. En: Medina, Cecilia y Mera, Jorge: Sistema Jurídico

y Derechos Humanos, Sociedad de Ediciones de la Universidad Diego Portales, 1996.

MEDINA, Gonzalo: "La primera declaración del imputado y el derecho a no declarar en perjuicio propio". En: Coloma, Rodrigo: La Prueba en el nuevo Proceso Penal Oral, Editorial Lexis Nexis, 2003.

MIRANDA, Manuel: La mínima actividad probatoria en el proceso penal, José María Bosch Editor, Barcelona, 1997.

MONTANEZZ, Miguel: La presunción de Inocencia. Análisis doctrinal y Jurisprudencial, Aranzadi Editorial, 1999.

NIEVA, Jordi: "Inmediación y valoración de la prueba : El retorno de la irracionalidad", visitado el 06/08/2012 en http://www.ichdp.cl/

old/inmediacion-y-valoracion-de-la-prueba-el-retorno-de-lairracionalidad.pdf

NOGUEIRA, Humberto: El debido proceso en la Constitución y el sistema interamericano, Editorial Librotecnia, Santiago de Chile, enero 2007.

POBLETE, Orlando: "Presunción de Inocencia, Significado y Consecuencias" en Revista del Abogado n 14, 1998.

POZO, Nelson: "Presunción de inocencia o estado de inocencia en el nuevo proceso penal”. En: Gaceta Jurídica año 2006, n³ 313, Julio.

RIEGO, Cristián: "La declaración del imputado en el juicio oral", http:/ /enj.org/portal/biblioteca/penal/la_prueba_proceso_penal/19.pdf visitado el 6 de agosto de 2012.

Revista de Ciencias Sociales - Número 64 (2014) - Universidad de Valparáíso - ISSN 0716-7725-Valparaíso, Chile 
ROMERO, Esteban: La presunción de inocencia. Estudio de alguna de las consecuencias de la de este derecho fundamental, Editorial Aranzadi, Pamplona, 1985.

TAPIA, Jorge: "Efectos de los Tratados sobre Derechos Humanos en la Jerarquía del Orden Jurídico y en la Distribución de Competencias: Alcances del nuevo inciso segundo del artículo $5^{\circ}$ de la CPR de 1980". Ius et Praxis. [online]. 2003, vol. 9, no.1 [citado 10 de octubre 2008].

VEGAS, Jaime: Presunción de Inocencia y Prueba en el Proceso Penal, Editorial La Ley, Madrid, 1993.

\section{SENTENCIAS}

Tribunal Constitucional Español $\mathrm{N}^{\circ} 31 / 1981$.

Tribunal Constitucional Chileno Rol 346- 2002.

Corte Suprema rol 4001-2010. 